УДК 677.021.017.86

О.В. ПАХОЛЮК

Луцьький національний технічний університет

В.І. ЛУБЕНЕЦЬ

Наиіональний університет "Львівська політехніка"

І.А. МАРТИРОСЯН

Одеська національна академія харчових технологій

\title{
ДОСЛІДЖЕННЯ ЕФЕКТИВНОСТІ БІОЦИДНИХ РЕЧОВИН ДЛЯ ОБРОБЛЕННЯ ОДЯГОВИХ ТЕКСТИЛЬНИХ МАТЕРІАЛІВ СПЕЦАЛЬНОГО ПРИЗНАЧЕННЯ
}

Е.В. ПАХОЛЮК

Луикий национальный технический университет

В.И. ЛУБЕНЕЦ

Национальный университет «Львовская политехника»

И.А. МАРТИРОСЯН

Одесская наџиональная академия пищевых технологий

\section{ИССЛЕДОВАНИЕ ЭФФЕКТИВНОСТИ БИОЦИДНЫХ ВЕЩЕСТВ ДЛЯ ОТДЕЛКИ ОДЕЖНЫХ ТЕКСТИЛЬНЫХ МАТЕРИАЛОВ СПЕЦИАЛЬНОГО НАЗНАЧЕНИЯ}

\author{
O. PAKHOLIUK \\ Lutsk National Technical University \\ V. LUBENETS \\ Lviv Politechnic National University \\ I.MARTIROSYAN \\ Odessa National Academy of Food Technologies
}

\section{INVESTIGATION OF THE EFFICIENCY OF BIOXIDE SUBSTANCES FOR THE TREATMENT OF SPECIAL TEXTILE MATERIALS}

\section{https://doi.org/10.36910/6775-2310-5283-2018-11-11}

Мета. Визначення ефективності використання досліджуваних біоцидних речовин для оброблення текстильних матеріалів спеціального призначення з метою підвищення їх грибостійкості.

Методика. При дослідженнях використовували передбачені діючими держсвними стандартами методи, які дозволяють визначення фунгіцидної та фунгістатичної активності деяких біоцидних препаратів відносно тест-культур, щуо згідно з нормативною документацією є біодеструкторами текстильних та інших промислових матеріалів.

Результати. Найбільш ефективними виявились препарати Фундазол та ЕTC. Причому, Фундазол майже однаково проявляв фунгіциину дію, тобто повністю перешкоджав розвитку грибів під кінецьь другого тижня від початку досліду та фунгістатичну дію, а саме, викликав затримку росту досліджуваних зразків грибів, у порівнянні з контрольним зразком у перщі два дні, при мінімальній концентрації препарату 
у розчині. Препарат Біфоназол проявив свою ефективність тільки до одного виду грибів, а cаме Aspergillus niger. Протягом усього дослідного періоду, ріст грибів був відсутній. У всіх решта випадках, він виявився неефективним. Препарат ETC показав високу ефективність проти всіх культур грибів, що використовували як тестові, але мінімальні дієві концентрачії були дещу вищі за ті, щуо декларуються в рекламі препарату.

Наукова новизна. Визначена ефрективна концентрація біоцидних речовин, щзо досліджуються, для оброблення текстильних матеріалів з метою підвищення їх зносостійкості.

Практична значимість. Представлені результати дослідження біоцидних препаратів для оброблення спеціальних текстильних матеріалів Подана порівняльна характеристика фунгіцицної та фунгістатичної дії досліджуваних препаратів на ефективність їх застосування.

Ключові слова: текстильні матеріали, біоџидні речовини, концентрація біоџидних речовин, фунгістатична дія, фунгіцидна дія, спецодяг, грибостійкість.

\section{Постановка проблеми у загальному вигляді і її зв'язок 3 важливими} науковими та практичними завданнями.

Під час експлуатації одягові текстильні матеріали, зокрема, спецодяг, можуть піддаватися негативному впливу різних чинників навколишнього середовища, а саме: змінам температури, опадів у вигляді дощу і снігу, туману, світлопогоди, мікроорганізмів тощо, що призводить до погіршення їхніх властивостей або руйнування i, як наслідок - до скорочення строку служби виробів з них. Останні роки характеризуються тенденцією зростання об’ємів виробництва тканих і нетканих одягових текстильних матеріалів спеціального призначення з натуральних волокон, а саме з бавовни. Особливо перспективно для розвитку вітчизняного текстильного виробництва використання волокон льону та коноплі, оскільки багаточисельні наукові та практичні дослідження показали можливість покращення функціональних, споживчих та екологічних властивостей виробів 3 них [1].

Умови виробництва та експлуатації натуральних одягових текстильних матеріалів спеціального призначення передбачають контакт 3 мікроорганізмами, інколи при підвищеній вологості повітря і температури, тому виникає ризик їх біодеструкції. Під впливом мікроорганізмів погіршується зовнішній вигляд виробів, з'являються плями, неприємний запах, знижуються показники надійності текстильних матеріалів, а в результаті втрачаються естетичні та експлуатаційні властивості $[1,2]$.

Розрізняють два принципових методи захисту текстильних матеріалів від мікропошкодження, а саме: пасивний та активний. При активного захисті гальмується утворення та розвиток мікроорганізмів на текстильному матеріалі, при активному - мікроорганізми знищуються. Але, проблема полягає в тому, що речовини, які використовуються для активного захисту від 
мікроорганізмів - біоцидні речовини, можуть виявлятися недостатньо стійкими та безпечними для людини та навколишнього середовища. У зв’язку 3 цим, для більшого забезпечення якісного рівня текстильних матеріалів, вітчизняні та зарубіжні виробники продовжують розробляти нові сучасні матеріали, що володіють комплексом необхідних споживних властивостей. В результаті цього, на українському ринку вслідкується щорічна поява нових тканин зі спеціальною структурою та видами оброблення, що відповідають підвищеним вимогам. Але актуальною проблемою залишається збереження натуральних властивостей та підвищення зносостійкості текстильних матеріалів, оброблених біоцидними препаратами, особливо тих, що призначені для виробництва спецодягу.

Аналіз останніх досліджень, у яких започатковано вирішення проблеми. Аналіз літературних джерел [1-5] дозволяє стверджувати, що біоцидні речовини забезпечують не тільки активний захист від негативної дії грампозитивних і грамнегативних бактерій, грибків та інших шкідливих мікроорганізмів, але й сприяють покращенню споживних властивостей текстильних матеріалів та підвищенню їх зносостійкості.

Ефективність та доцільність надання біоцидних властивостей текстильним матеріалам обумовлено результатами досліджень зарубіжних та вітчизняних вчених у цьому напрямку. Особливо можна відзначити роботи таких вчених як Кричевський Г.Е, Разуваев А.В., Калонтаров І.Я., Глубіш П.А, Супрун Н.П., в яких досліджувались можливості надання біоцидних властивостей текстильним матеріалам та підвищенню їх стійкості до мікробіологічних пошкоджень. Проблемам формування та оцінки біостійкості текстильних матеріалів та виробів побутового, технічного та спеціального призначення, присвячені роботи таких видатних вчених, як Семак Б. і Галик I.

Але незважаючи на високі досягнення в цьому напряму, на світовому ринку до теперішнього часу переважають традиційні біоцидні препарати: хлорактивні, четвертинні амонієві сполуки, а також сполуки, які містять токсичні з'єднання міді, кадмію, олова, свинцю тощо. I разом з тим, існує ряд проблем при створенні текстильних матеріалів із бактерицидними властивостями. Сучасні біоцидні речовини хоча й подавляють більшість мікроорганізмів, але недостатньо ефективні, а деякі 3 них токсичні та небезпечні для людини і навколишнього середовища.

Метою статті $є$ визначення ефективності використання досліджуваних біоцидних речовин для оброблення текстильних матеріалів спеціального призначення з метою підвищення їх грибостійкості. 
Виклад основного матеріалу дослідження 3 повним обгрунтуванням отриманих наукових результатів. 3 метою визначення ефективності використання досліджуваних біоцидних матеріалів призначених для спецодягу та визначення ефективної їх концентрації, у секторі мікології і мікотоксикології Державного науково-контрольного інституту біотехнології і штамів мікроорганізмів нами було проведено дослідження фунгіцидної та фунгістатичної активності деяких біоцидних препаратів відносно тесткультур, що згідно 3 нормативною документацією $є$ біодеструкторами текстильних та інших промислових матеріалів згідно з вимогами ГОСТ 9.048 «Изделия технические. Методы лабораторных испытаний на стойкость к воздействию плесневых грибов» [6] та ГОСТ 9802 «Ткани и изделия из натуральних, искусственных, синтетических волокон и их смесей. Метод испытания на грибостойкость» [7].

Для дослідження були підібрані такі культури грибів, що депоновані в національному центрі штамів мікроорганізмів ДНКІБШМ:

- trihoderma viride Pers. ex S.F. Gray;

- aspergillus niger van Tieghem;

- penicillium funiculosum Thom;

- paecilomyces variotii Bainier;

- chaetomium globosum Kunze.

Активність препаратів визначали суспензійним методом згідно 3 керівництвом «Р 4.2. 2643 - 10 - Методы лабораторных исследований и испытаний дезинфекционных средств для оценки их эффективности и безопасности».

Нами були досліджені такі біоцидні препарати:

1. Фундазол (беноміл) - препарат широкого діапазону, системної дії; використовується для боротьби з патогенами наземної частини рослин та як протруювач насіння та цибулин для запобігання їх пліснявіння.

2. Біфоназол - препарат, ефективний проти дерматофітів - збудників захворювань шкіри людей та тварин.

3. ЕТС (етилтіосульфанілат) - препарат протигрибковий 3 багатовекторними фармакодинамічними проявами для лікування дерматомікозів та захисту промислових товарів широкого діапазону від біодеструкторів. Запатентований ЕТС як біоцид для захисту нафтопродуктів, матеріалів та обладнання.

Дослідження проводили з використанням рідкого середовища Сабуро. Наважку препарату або його розчин (для ЕТС) вносили в першу пробірку з 10 
мл середовища Сабуро. Таким чином отримували середовище з найвищою концентрацією. Після ретельного перемішування половину (фундазол та біфоназол) або третину (ЕТС) об'єму розчину препарату переносили у наступні пробірки 3 відповідною кількістю середовища. Таким чином послідовно розводили біоцид удвічі або втричі. Потім у кожну пробірку з 5 мл середовища додавали по 0,2 мл суспензії тест-гриба, тобто вносили не менше як по $10^{6}$ КУО, ретельно перемішували, скошували на штативі для збільшення площі аерації і ставили в термостат з температурою $28^{\circ} \mathrm{C}$.

Дослід повторювали тричі в однакових умовах. Облік розвитку тесткультур проводили щоденно впродовж двох тижнів. Визначали наявність або відсутність росту порівняно 3 контролем, яким було рідке поживне середовище без препарату. Запис вели у хрестах (за 4-бальною шкалою):

- ріст відсутній,

$+\quad$ - окремі пластівці в рідкому середовищі.

++ - суцільний ріст глибинного міцелію,

+++ - початок формування повітряного міцелію,

++++ - формування повітряного міцелію по всій площі середовища.

Варіювання оцінок по повторностях було мінімальним і різниця не перевищувала одного хреста, тому за результат, брали вищу з концентрацій. Фунгистатичною дією вважали - затримку росту досліджуваних зразків, у порівнянні з контрольним зразком у перші два дні. Фунгіцидною вважали концентрацію, яка повністю перешкоджала розвитку грибів під кінець другого тижня від початку досліду. Результати досліджень представлені у таблиці 1.

3 аналізу даних таблиці, можна зробити висновок, що найбільш ефективними виявились препарати Фундазол та ЕТС. Причому, Фундазол майже однаково проявляв фунгіцидну дію, тобто повністю перешкоджав розвитку грибів під кінець другого тижня від початку досліду та фунгістатичну дію, а саме, викликав затримку росту досліджуваних зразків грибів, у порівнянні з контрольним зразком у перші два дні, при мінімальній концентрації препарату у розчині. Для усіх досліджуваних культур грибів, мінімально дієвою була концентрація 0,015 \% для Trihoderma viride i 0,008 \% - для решти культур грибів.

Препарат Біфоназол проявив свою ефективність тільки до одного виду грибів, а саме Aspergillus niger. Протягом усього дослідного періоду, ріст грибів був відсутній. У всіх решта випадках, він виявився неефективним. 


\section{Таблиця 1}

\section{Вплив біоцидних речовин різних концентрацій, на розвиток цвілевих грибів}

\begin{tabular}{|c|c|c|c|c|c|c|c|c|}
\hline \multirow{2}{*}{$\begin{array}{c}\begin{array}{c}\text { Досліджуваний } \\
\text { препарат }\end{array} \\
1\end{array}$} & \multicolumn{8}{|c|}{$\begin{array}{c}\text { Розвиток культур цвілевих грибів за 4-бальною шкалою, } \\
\text { при зменшенні концентрації }\end{array}$} \\
\hline & 2 & 3 & 4 & 5 & 6 & 7 & 8 & 9 \\
\hline \multicolumn{9}{|c|}{ Trihoderma viride } \\
\hline \multirow{3}{*}{$\begin{array}{l}\text { Фундазол, \% } \\
\mathrm{A}^{1} \\
\mathrm{~b}^{2}\end{array}$} & 1 & 0,5 & 0,25 & 0,12 & 0,06 & 0,03 & 0,015 & 0,008 \\
\hline & -3 & - & - & - & - & - & $t^{4}$ & + \\
\hline & - & - & - & - & - & - & $-/+$ & + \\
\hline \multirow{3}{*}{$\begin{array}{l}\text { Біфоназол, \% } \\
\text { А } \\
\text { Б }\end{array}$} & 1 & 0,5 & 0,25 & 0,12 & 0,06 & 0,03 & 0,015 & 0,008 \\
\hline & + & $++++^{7}$ & ++++ & ++++ & ++++ & ++++ & ++++ & ++++ \\
\hline & - & - & + & + & $++^{5}$ & ++ & ++ & ++ \\
\hline \multirow{3}{*}{$\begin{array}{l}\text { ETC, \% } \\
\text { A } \\
\text { Б }\end{array}$} & 0,5 & 0,16 & 0,055 & 0,0185 & 0,006 & 0,002 & 0,0007 & 0,0002 \\
\hline & - & - & + & ++ & $++++^{6}$ & ++++ & ++++ & ++++ \\
\hline & - & - & - & - & + & ++ & ++ & ++ \\
\hline \multicolumn{9}{|c|}{ Aspergillus niger } \\
\hline \multirow{3}{*}{$\begin{array}{l}\text { Фундазол, \% } \\
\text { А } \\
\text { Б }\end{array}$} & 1 & 0,5 & 0,25 & 0,12 & 0,06 & 0,03 & 0,015 & 0,008 \\
\hline & - & - & - & - & - & - & - & ++++ \\
\hline & - & - & - & - & - & - & - & - \\
\hline \multirow{3}{*}{$\begin{array}{l}\text { Біфоназол, \% } \\
\text { А } \\
\text { Б }\end{array}$} & 1 & 0,5 & 0,25 & 0,12 & 0,06 & 0,03 & 0,015 & 0,008 \\
\hline & - & - & - & - & - & - & - & - \\
\hline & - & - & - & - & - & - & - & - \\
\hline \multirow{3}{*}{$\begin{array}{l}\text { ETC, \% } \\
\text { A } \\
\text { Б }\end{array}$} & 0,5 & 0,16 & 0,055 & 0,0185 & 0,006 & 0,002 & 0,0007 & 0,0002 \\
\hline & - & - & - & ++ & ++++ & ++++ & ++++ & ++++ \\
\hline & - & - & - & ++ & ++ & +++ & +++ & +++ \\
\hline 1 & 2 & 3 & 4 & 5 & 6 & 7 & 8 & 9 \\
\hline \multicolumn{9}{|c|}{ Penicillium funiculosum } \\
\hline \multirow{3}{*}{$\begin{array}{l}\text { Фундазол, \% } \\
\text { А } \\
\text { Б } \\
\end{array}$} & 1 & 0,5 & 0,25 & 0,12 & 0,06 & 0,03 & 0,015 & 0,008 \\
\hline & - & - & - & - & - & - & - & + \\
\hline & - & - & - & - & - & - & - & + \\
\hline \multirow{3}{*}{$\begin{array}{l}\text { Біфоназол, \% } \\
\text { А } \\
\text { Б }\end{array}$} & 1 & 0,5 & 0,25 & 0,12 & 0,06 & 0,03 & 0,015 & 0,008 \\
\hline & - & - & +++ & ++++ & ++++ & ++++ & ++++ & ++++ \\
\hline & - & - & - & ++ & ++++ & ++++ & ++++ & ++++ \\
\hline \multirow{3}{*}{$\begin{array}{l}\text { ETC, \% } \\
\text { A } \\
\text { Б }\end{array}$} & 0,5 & 0,16 & 0,055 & 0,0185 & 0,006 & 0,002 & 0,0007 & 0,0002 \\
\hline & - & - & - & - & ++ & ++ & ++ & +++ \\
\hline & - & - & - & - & + & ++ & ++ & +++ \\
\hline \multicolumn{9}{|c|}{ Paecilomyces variotii } \\
\hline \multirow{2}{*}{$\begin{array}{l}\text { Фундазол, \% } \\
\text { А }\end{array}$} & 1 & 0,5 & 0,25 & 0,12 & 0,06 & 0,03 & 0,015 & 0,008 \\
\hline & - & - & - & - & - & & - & + \\
\hline
\end{tabular}


Товарознавчий вісник. - 2018. - Випуск 11.

\begin{tabular}{|c|c|c|c|c|c|c|c|c|}
\hline Б & - & - & - & - & - & - & + & ++ \\
\hline \multirow{3}{*}{$\begin{array}{l}\text { Біфоназол, \% } \\
\text { А } \\
\text { Б }\end{array}$} & 1 & 0,5 & 0,25 & 0,12 & 0,06 & 0,03 & 0,015 & 0,008 \\
\hline & - & - & +++ & ++++ & ++++ & ++++ & ++++ & ++++ \\
\hline & - & - & - & ++ & ++++ & ++++ & ++++ & ++++ \\
\hline \multirow{3}{*}{$\begin{array}{l}\text { ETC, \% } \\
\text { A } \\
\text { Б }\end{array}$} & 0,5 & 0,16 & 0,055 & 0,0185 & 0,006 & 0,002 & 0,0007 & 0,0002 \\
\hline & - & - & - & - & + & ++ & +++ & +++ \\
\hline & - & - & - & - & + & ++ & +++ & +++ \\
\hline \multicolumn{9}{|c|}{ Chaetomium globosum } \\
\hline \multirow{3}{*}{$\begin{array}{l}\text { Фундазол, \% } \\
\text { А } \\
\text { Б }\end{array}$} & 1 & 0,5 & 0,25 & 0,12 & 0,06 & 0,03 & 0,015 & 0,008 \\
\hline & - & - & - & - & - & - & - & + \\
\hline & - & - & - & - & - & - & - & +- \\
\hline \multirow{3}{*}{$\begin{array}{l}\text { Біфоназол, \% } \\
\text { А } \\
\text { Б }\end{array}$} & 1 & 0,5 & 0,25 & 0,12 & 0,06 & 0,03 & 0,015 & 0,008 \\
\hline & - & + & ++ & +++ & +++ & ++++ & ++++ & ++++ \\
\hline & - & - & + & ++ & ++ & ++ & ++ & ++ \\
\hline \multirow{3}{*}{$\begin{array}{l}\text { ETC, \% } \\
\text { A } \\
\text { Б }\end{array}$} & 0,5 & 0,16 & 0,055 & 0,0185 & 0,006 & 0,002 & 0,0007 & 0,0002 \\
\hline & - & - & - & + & ++ & +++ & +++ & ++++ \\
\hline & - & - & - & - & + & ++ & ++ & ++ \\
\hline
\end{tabular}

Примітка: $\mathrm{A}^{1}$ - фунгіцидна дія препарату, яка повністю перешкоджала розвитку грибів під кінець другого тижня від початку досліду;

$Б^{2}-$ фунгістатична активність препаратів проти грибів тест-культур, яка викликає затримку росту досліджуваних зразків, у порівнянні з контрольним зразком у перші два дні;

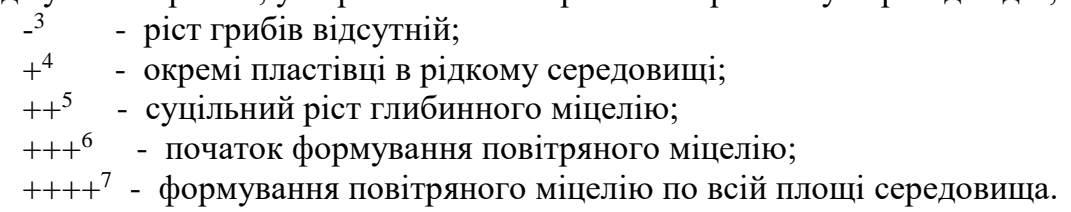

Препарат ЕТС показав високу ефективність проти всіх культур грибів, що використовували як тестові, але мінімальні дієві концентрації були дещо вищі за ті, що декларуються в рекламі препарату. Мінімальна фунгіцидна властивість препарату проявлялась при концентрації препарату в розчині $0,0185 \%$, а фунгістатична дія, при концентрації - 0,006 \%, тобто втричі меншій.

Висновки та перспективи подальших досліджень. В результаті проведених досліджень, можна зробити висновок, що два препарати, а саме Біфоназол та ЕТС, мають високу фунгіцидну та фунгістатичну активність, щодо таких культур грибів, як Trihoderma viride Pers. ex S.F. Gray, Aspergillus niger van Tieghem, Penicillium funiculosum Thom, Paecilomyces variotii Bainier,Chaetomium globosum Kunze i можуть виступати біодеструкторами грибкових мікроорганізмів текстильних матеріалів.

Оскільки, обрані нами типи препаратів вибірково гальмують життедіяльність окремих класів грибів, тому це дозволяє цілеспрямовано 
виокристовувати такі препарати для оброблення різних за призначенням текстильних матеріалів залежно від конкретних умов їх експлуатації.

Проте, враховуючи швидку адаптацію мікробних культур до несприятливих факторів, токсичність та алергенність багатьох існуючих препаратів, необхідно проводити пошук нових біоцидів, а також раціональних технологій їх застосування.

\section{Література}

1. Пахолюк О.В. Особливості використання лляних волокон у виготовленні медичного текстилю / О.В. Пахолюк, О.І. Передрій // Вісник ХНУ. - 2017. - № 1. - С. 56 60.

1. Разуваев А.В. Природные антимикробные свойства натуральных волокон и вопрос их дополнительной биоцидной отделки. Текстильная промышленность. 2011. №5. С. 38-42.

2. Калонтаров И.Я. Придание текстильным материалам биоцидных свойств и устойчивости к микроорганизмам / И.Я. Калонтаров, В.Л. Ливерант. - Душанбе, 1981. 202 c.

3. Галик І.С., Семак Б.Д. Екологічна безпека та біостійкість тестильних матеріалів. монографія. І.С. Галик, О.Б. Концевич,- Львів : Видавництво Львівської комерційної академії, 2006. - 232 с.

4. Галик, I. С., Семак Б. Д. Проблеми формування та оцінювання екологічної безпечності текстилю. Монографія. Львів: Видавництво Львівської комерційної академії, 2014. $-488 \mathrm{c}$.

5. Кричевский Г.Е. Нано-, био-, химические технологии в производстве нового поколения волокон, текстиля и одежды. Монография. М.: Издательство «Известия», 2011. $528 \mathrm{c}$.

6. Изделия технические. Методы лабораторных испытаний на стойкость к воздействию плесневых грибов: ГОСТ 9.048-89. ЕСЗКС. [Введен от 1991-01-07]. - М.: Изд-во стандартов:1991. - 23 с. - (Государственный стандарт союза ССР).

7. Ткани и изделия из натуральных, искусственных, синтетических волокон и их смесей. Метод испытания на грибостойкость: ГОСТ 9.802-84. ЕСЗКС. - [Введен от 1985-01-01]. - М.: Изд-во стандартов, 1984. - 6 с. - (Государственный стандарт союза ССР).

Цель. Определение эффективности использования исследуемых биоцидных веществ для обработки текстильных материалов специиального назначения с ичелью повышения их грибостойкости.

Методика. В процессе исследований использовали предусмотренные действующими стандартами методы, позволяющие определять фунгищидную и фунгистатическую активность некоторых биочидных препаратов относительно тест-культур, которые согласно нормативной документации являются биодеструкторами текстильных и других промышленных материалов.

Результаты. Наиболее эффективными оказались препараты Фундазол и ЭТС, при этом Фундазол показал почти одинаковое фунгициное действие, полностью предупредив развитие грибов в конще второй недели от начала исследований, и фунгистатическое действие, вызывая задержку роста грибов в исследуемых образиах в сравнении с контрольнылм образиом в первые два дня при минимальной конщентрации препарата в растворе. Препарат Бифиназол оказался эффективным только против одного вида 
грибов, в частности Aspergillus niger, поскольку в течение всего исследуемого периода рост грибов отсутствовал. В остальных случаях данный биочии оказался неэффективным. Препарат ЭТС показал высокую эффективность против всех культур грибов, которые использовались в роли тестовых.

Научная новизна. Определена эффективность исследуемых биоцидных веществ для обработки текстильных материалов с иелью повышения их износостойкости.

Практическая значимость. Представлень результаты исследования биочидных препаратов для обработки спещиальных текстильных материалов. Приведена сравнительная характеристика фунгищидного и фунгистатического действия исследуемых препаратов по эффективности их использования.

Ключевые слова: текстильные материаль, биоцидные вещества, концентрация биочидных веществ, фунгистатическое действие, спецоодеда, грибостойкость.

Aim. Determining the efficiency of investigated biocidal substances for treatment of textile materials with special purposes to improve their fungus resistance.

Method. During the studies methods standards were used provided by the current state that allow the determination of the fungicidal and fungistatic activity of certain biocidal preparations in relation to test cultures, which according to the normative documentation are biodestructors of textile and other industrial materials.

Results. The most efficacious drugs were Fundazol and ETS (ethylthiosulfanilate). Moreover, Fundazol almost equally showed a fungicidal action, that completely prevented the development of fungi at the end of the second week from the beginning of the experiment and fungistatic effect, namely, caused growth retardation of the studied samples of fungi, compared with the control sample in the first two days, with a minimum concentration of the preparation in solution The drug Bifonazole has shown its effectiveness only to one type of fungi, namely Aspergillus niger. During the entire trial period, the growth of fungi was absent. In all other cases, it was ineffective. The ETS showed the high efficiency against all fungal cultures used as a test, but the minimum effective concentrations were slightly higher than those declared in the drug advertising.

Scientific novelty. The effective concentration of investigated biocidal substances is determined for the processing of textile materials in order to increasing their wear resistance.

Practical significance. The results of research about biocidal preparations for processing of special textile materials are presented. The comparative characteristic of fungicidal and fungistatic action of investigated preparations towards the efficiency of their application is shown.

Keywords: textile materials, biocidal substances, concentration of biocidal substances, fungistatic action, fungicidal action, overalls, fungus resistance.

Стаття рекомендована до публікаиії професором Байдаковою О.I. Стаття надійшла в редакцію 29.01.2018 p. 